Research, part of a Special Feature on The influence of human demography and agriculture on natural systems in the Neotropics

\title{
A Peri-Urban Neotropical Forest Transition and its Consequences for Environmental Services
}

\author{
$\underline{\text { H Ricardo Grau }}^{1,2}, \underline{\text { María Eugenia Hernández }}^{1}, \underline{\text { Jorgelina Gutierrez }}^{1}, \underline{\text { N. Ignacio Gasparri }}^{1,2}$, \\ M. Cristina Casavecchia $^{3}$, Emilio E. Flores-Ivaldi ${ }^{1}$, and Leonardo Paolini ${ }^{1,2}$
}

\begin{abstract}
We analyzed changes in land cover in the Sierra de San Javier and its surroundings, an area of ca. 70000 ha near San Miguel de Tucumán, an urban center of ca. 1 million people in subtropical Argentina. The analysis covered two periods: 1949-1972 and 1972-2006 using remote sensing techniques. For the year 2001, we mapped the patterns of distribution of secondary forests dominated by the most abundant exotic tree species (Ligustrum lucidum). Based on land-cover maps, we estimated sediment yield as an index of watershed condition. Urban area was growing during the whole study period. Between 1949 and 2006, forest area increased approximately 1400 ha, mostly over abandoned agriculture and grasslands; this expansion was accelerated between 1972 and 2006. Increased forest cover resulted in a reduction in erosion and sediment yield that was disproportionately large, as most new forests are located in areas of steep slopes and high rainfall. By 2001, Ligustum-dominated forests had expanded to more than 500 ha, in the southern portion of the sierra only. Overall, the analysis quantifies a process of Neotropical periurban forest transition, likely associated with socioeconomic changes related to population urbanization, that promotes improvements of some environmental services, such as watershed and biodiversity conservation. However, natural communities are strongly affected by past land use and neighboring urban areas, which have promoted a growing importance of exotic species with mostly unknown ecological consequences.
\end{abstract}

Key Words: exotic species invasion; forest transition; GIS; land-use change; subtropical Argentina; urbanization; watershed conservation; yungas

\section{INTRODUCTION}

Land use and land cover (LUC) play a central role in defining the capacity of terrestrial ecosystems to provide environmental services. In forested biomes, forest cover is probably the single most important descriptor of LUC, and is a main control of environmental services such as erosion control, carbon sequestration, and biodiversity conservation. In general, forest recovery improves watershed conservation (Mather and Fairnbarn 2000) and carbon sequestration (Grau et al. 2004). Recent papers have argued that expanding secondary forests associated with population urbanization could also play a significant role in favoring biodiversity recovery in Neotropical ecosystems (Lugo 2002, Grau et al. 2003, 2007, Hecht et al. 2006), to the point that this process may help mitigate the so-called biodiversity crisis (Aide and Grau 2004, Wright 2005, Wright and MullerLandau 2006). But, forest cover can be an incomplete index. For example, increasing forest cover is frequently composed of exotic monospecies stands, which hardly contribute to biodiversity (Rudel et al. 2005). Therefore, in addition to forest cover area, it is important to assess the composition of these forests.

Forest transition, the reversal of trends in LUC change from deforestation to reforestation, has been well documented in the temperate forests of Europe (Mather 1992) and North America (Veblen and Lorenz 1991, Foster 1992). This change occurs in association with socioeconomic changes related to a modern economy, including agricultural adjustment to the most productive soils, rural to 
urban migration, increases in transport and information technology, decreasing dependence on local resources, and government conservation policies derived from the increased awareness of potential environmental crises (Mather 2001). As many developing tropical countries are undergoing this sort of socioeconomic change, they could experience forest transition. And, in fact, forest recovery has been documented in different areas of the Caribbean, México, and Central and South America (Grau and Aide 2008).

One particular case of forest transition is when it occurs near to large urban centers. This type of local LUC change differs from more extensive regionalscale processes in two ways. First, recovering natural areas are likely to be more affected by the direct effects of urbanization, including a diverse source of potential invader organisms. Second, a large and concentrated human population is directly affected by the changes in the environmental services provided by the surrounding landscapes. Mid-sized urban centers are the ones growing fastest globally (United Nations Population Fund (UNFPA) 2007), therefore, assessing the patterns and ecological consequences of LUC change in the vicinity of mid-sized cities is particularly relevant for sustainable development in the present and coming decades. However, studies on the ecological effects of forest transition in peri-urban Neotropical landscapes are scarce. The most detailed analyses of the ecological consequences of this process have been conducted in Puerto Rico, a highly urbanized Caribbean island. Much of the new Puerto Rican ecosystems is strongly influenced by the abundance of exotic species (Aide et al. 2000, Lugo and Helmer 2004). But, despite these invaders, massive forest expansion during the last 50 years has led to the recovery of local diversity of plants, different insect groups, and earthworms (Grau et al. 2003), and has prevented the extinction of a rich biological community (Lugo 2002). However, the particular conditions of Puerto Rico both in ecological and socioeconomic terms (an island frequently affected by hurricanes and highly influenced by its strong links with the USA), imply some caveats for extrapolating these observations to the rest of the Neotropics (Grau et al. 2003), and research is needed in a wider range of peri-urban situations.

Here, we describe the patterns and some ecological consequences of a process of forest transition in the vicinity of San Miguel de Tucumán, the largest urban center in subtropical Argentina. The two main specific objectives of the paper were: (1) To describe patterns of LUC change during the last 50 years, including an analysis of the distribution of forests dominated by the most abundant exotic tree species. Based on these analyses, we discuss the potential effects of LUC changes on biodiversity conservation. (2) To quantify the effects of these LUC changes on sediment yields as an index of watershed quality.

\section{METHODS}

The study focused on the Sierra de San Javier, a mountain range located about $15 \mathrm{~km}$ west of the city of San Miguel de Tucumán, Tucumán province, Argentina, between $26^{\circ} 39^{\prime}$ to $26^{\circ} 54^{\prime} \mathrm{S}$ and between $65^{\circ} 17^{\prime}$ to $65^{\circ} 27^{\prime} \mathrm{W}$ (Fig. 1 ). Our analysis has two main components: (1) We analyzed the changes in LUC between 1949 and 2006 in two periods (before and after 1972). In addition, for the year 2001, we mapped the distribution of forests dominated by Ligustrum lucidum, the most abundant exotic tree species. (2) We assessed the effects of land-use trends on watershed conservation, by analyzing the changes in sediment yields between 1972 and 2006.

\section{Study Area}

The San Javier mountain range has a dominant north-south direction (Fig. 1), and covers an elevational range from $500 \mathrm{~m}$ in the eastern foothills to $1876 \mathrm{~m}$ on the mountain top. The climate is subtropical with a monsoonal rainfall regime (dry winters, rainy summers). Temperature and rainfall are strongly controlled by topography (Hunzinger 1997). During the second half of the $20^{\text {th }}$ century, regional precipitation has increased (Minetti and Vargas 1997), likely in association with global atmospheric changes (Labraga 1997).

Natural vegetation is dominated by subtropical montane forests, with local variations in vegetation due to topography. Yungas semi-evergreen forests cover most of the area, including the eastern, southern, and southwest slopes. Northwestern slopes are dominated by Chaco dry forests and shrublands, and natural foggy grasslands spread over some sectors of the mountain top (Moyano and Movia 1989). The grasslands area has likely been extended due to past extensive grazing. Secondary forests occur near to agricultural and urban sectors 
Fig. 1. Study area indicating location in South America and Argentina, main urban centers, and zonation of different types of analyses. (A) indicates the sector classified using on-screen visual digitalization, and (B) indicates the sector classified using spectral analysis.
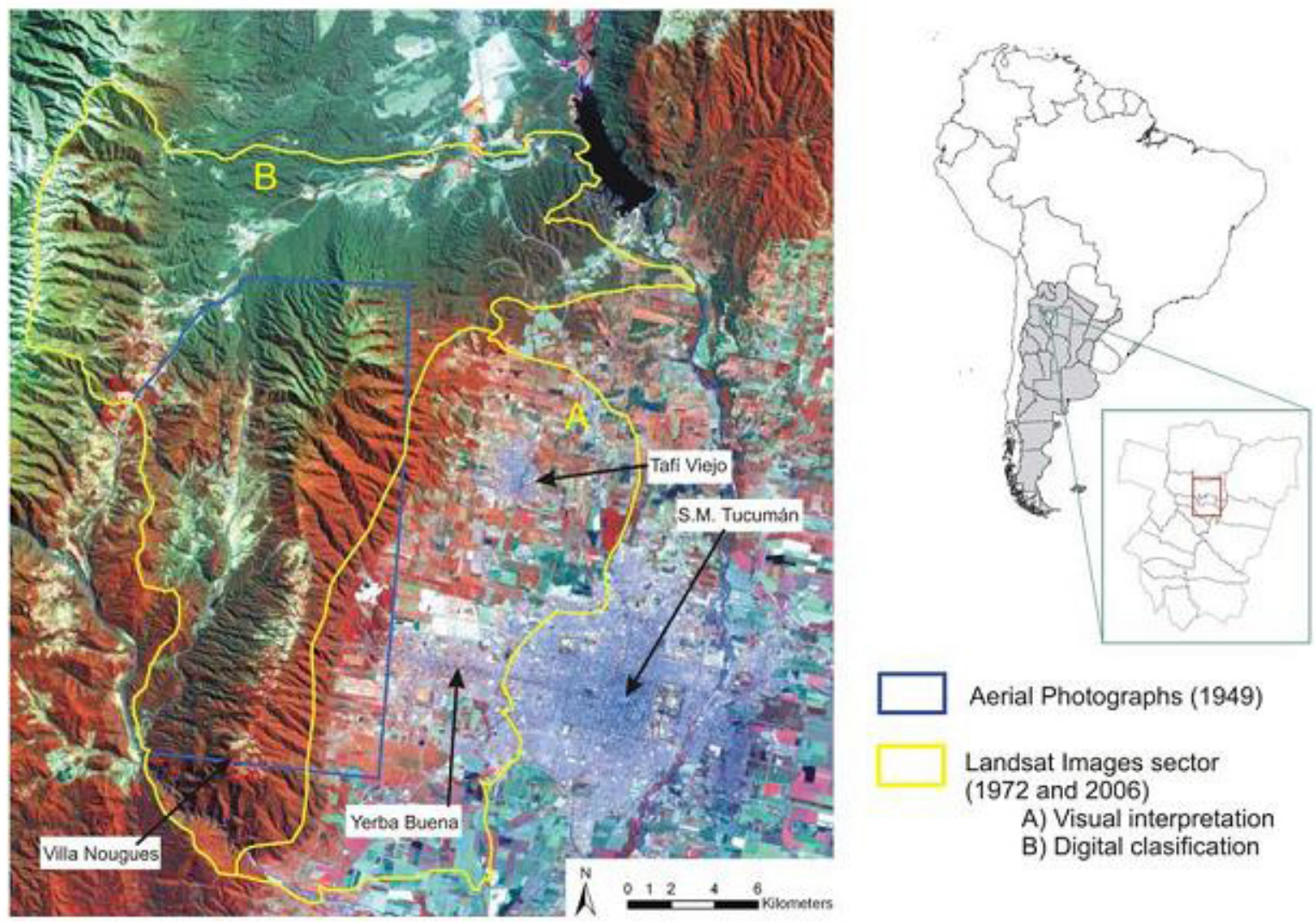

Aerial Photographs (1949)

Landsat Images sector (1972 and 2006)

A) Visual interpretation

B) Digital clasification

(Grau et al. 1997; Aragón and Morales 2003) and where grazing intensity has decreased (Arturi et al. 1998, Carilla et al. 2006). The most abundant secondary tree species is Ligustrum lucidum (Grau and Aragón 2000, Aragón and Morales 2003), an exotic species of Asian origin. Monodominant $L$. lucidum secondary forests have lower species diversity in different plant functional groups compared with native-dominated secondary forests (Lichstein et al. 2004).

The area includes different land uses. The centralsouth ridge is used for extensive grazing and lowdensity human housing; in the past cattle grazing was also important inside the forest. The western valleys include several hundred hectares of intensive agriculture (mostly summer horticulture) as well as grazing. In the past, selective logging focused on the most valuable timber species (Cedrela lilloi) affected a large proportion of the sierra. Land uses in the eastern foothills include modern agriculture (sugar cane, citrus, horticulture, floriculture) and expanding urbanization. Approximately 14000 ha of the study area are included in a protected area owned by the National University of Tucumán created in the mid 1970s (Parque Sierra de San Javier, Fig. 2c). In addition to the protected area, there have been some restrictions to 
Fig. 2. Main LUC categories in 1972 (A), 2006 (B), and changes between the two dates (C).

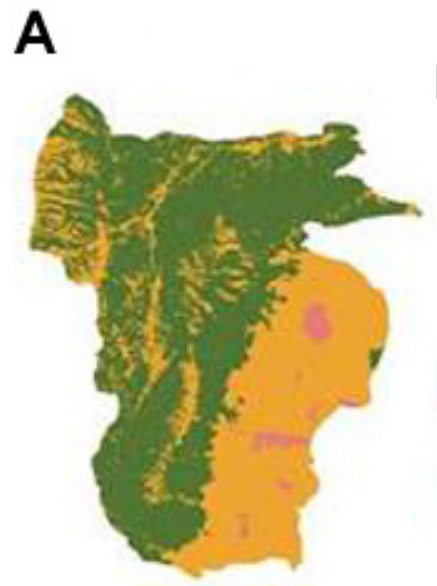

1972

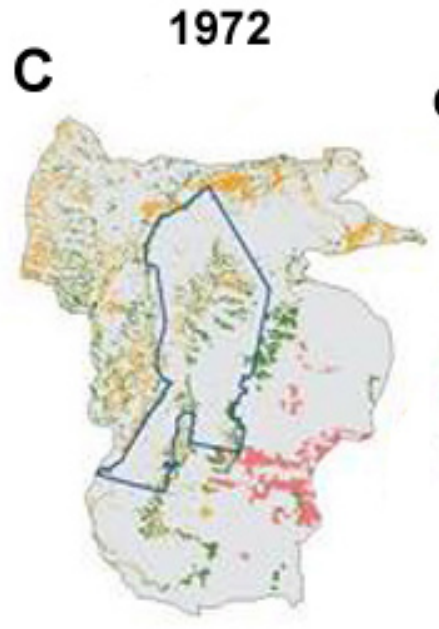

B

Land use

Agriculture/ pasture

Forest

Urban

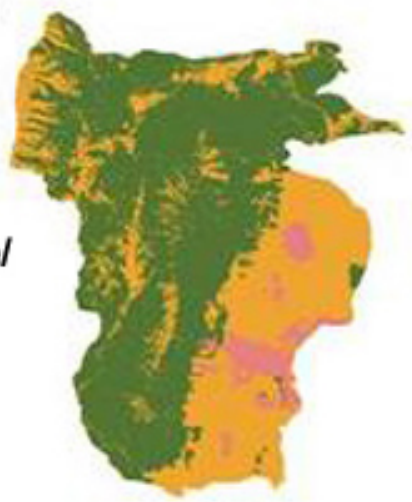

2006

\section{Changes}

\section{Forest to Agriculture/pasture}

Agriculture/pasture to Forest

\section{Agriculture to Urban}

Parque Sierra San Javier

agricultural development in the southern sector of the San Javier range, but these policies generally lacked legal enforcement. The Grand San Miguel de Tucumán, located in the eastern foothills of the sierra and including the towns of Yerba Buena and Tafí Viejo in close contact with the sierra, currently has a population of about 900000 . Between 1980 and 2001, the municipality of San Miguel de Tucumán increased from 380000 inhabitants to 527 $000(+38 \%)$, whereas during the same period, the department of Yerba Buena (which extends into the southern part of the Sierra de San Javier) increased from 36000 to $63000(+75 \%)$. Although agriculture continues to be an important economic activity (particularly in the eastern foothills and western valleys), the local economy is now dominated by services for the growing urban center, and some tourism developments, mostly for the domestic market.

\section{Land-Cover Change}

To compare changes in land use and land cover, we used aerial photographs at a scale of 1:50 000 for 1949, Landsat MSS images taken 3 September 1972, and Landsat ETM+ images taken 18 September 2006. The total area of analysis is 69891 ha (Fig. 1). Due to deformations arising from the topography, the 1949 analysis only quantifies area of different land-cover categories by means of onscreen visual digitalization, but was not used for 
spatially explicit analyses. The 1972 image was coregistered with the 2006 image using 20 non-variant control points (e.g., buildings, crossroads), with an error of $76.33 \mathrm{~m}$ (approximately one MSS pixel).

Three land-cover categories (agriculture and grasslands, forests, and urban) were discriminated using two different methodological approaches in the images of 1972 and 2006. In the western foothills of the sierra (Fig. 1), with a high cover of modern agriculture and all the urban zones of the study area, we conducted an on-screen visual digitalization that was adequate to discriminate forests from lowdensity urbanization and diverse agricultural cover with different spectral properties (citrus, sugar cane, annual crops), based on spatial patterns combined with spectral characteristics. In the rest of the area, corresponding to the mountains, hills, and western valleys, the land cover is dominated by forest and grassland with only few agricultural plots and no urban areas. In this sector, we used supervised classifications for the two dates, using as training sites field observations in 2007 for 2006, and aerial photographs at a scale of 1:50 000 taken in 1968 for 1972. The 1972 image classification used three classes: (i) agriculture and grasslands, (ii) dry forests, and (iii) evergreen forests. Reference spectral signatures were defined based on 15 training sites for each category. Separability (transformed divergence; Richards and Xiuping 2006) between forests and agriculture/grasslands was 1.6 for dry forests and 2 for evergreen forests (separability varies between 1 and 2 , where 2 is maximum). For the 2006 classification, we also considered forests dominated by Ligustrum lucidum and pine plantations. For this classification, separability between agriculture and dry forests was 1.94, and separability between agriculture/ grasslands and all the other forest types was 2 . For the classification process, we used different classes of forest (dry and evergreen in 1972 and dry, evergreen Ligustrum and pine plantation in 2006) to avoid using "hybrid" spectral signatures of forest of different types. We finally merged these forest classes into a single one to generate a binary digital classification: forest and non-forest, resampled to $86 \times 86 \mathrm{~m}$ resolution (digital elevation model (DEM) resolution used for sediment study). In addition, the on-screen digitizing information of the eastern sector of the study area was transformed to a raster format with the same resolution, which yielded as a final result two layers (1972 and 2006) with three resulting classes: forests, agriculture/ grasslands, and urban.
To assess the accuracy of this final classification, we generated a triangular grid where we allocated cells of $1 \mathrm{~km} \mathrm{X} 1 \mathrm{~km}$ regularly, overlaid on the classified images. On this grid, we sampled 443 cells for the 1972 image and 808 cells for the 2006 image. For each one of these cells, we compared the landcover class derived from our digital classification with a visual classification obtained from highresolution remote sensing, to generate a confusion matrix. The 1972 classification map was compared with 1:50 000 aerial photographs taken in 1968, and the 2006 classification was compared with Google Earth mosaics derived from Quick Bird images taken in 2002 and 2006. The overall precision (Kappa coefficient; Foody 2002) was $88.04 \%$ for the 1972 classification and $87.87 \%$ for the 2006 classification; the class with lower errors being forests, and the class with higher errors being urban (Appendix 1)

To map the distribution of Ligustrum lucidum forests, we focused on the southern sector of the study area, where the species is more abundant. First, we used Landsat ETM+ images of different seasons (June $=$ winter; September $=$ early spring; December $=$ late spring) in 2001 to assess during which season Ligustrum forests are better discriminated from native forests. We selected the image of September, in which the separability (Richards and Xiuping 2006) between native forests and Ligustrum-dominated forests was greater, especially in band $4=$ near infrared ("transformed divergence" $=1.95$ ). Based on this, we conducted a supervised classification of an image taken on 25 September 2001, using bands 1, 2, 3, 4, 5, and 7; and we applied a "majority" 3 X 3 filter to obtain the final thematic map. To assess the precision of the classification, we used 96 ground control points distributed across the study area, in which between 2003 and 2005, we determined land cover in the field and located these groundtruthing points on the map with a Geographic Positioning System (GPS). These points were used to construct a vector point layer in the GIS to be compared with the classification map, yielding an overall precision of $96 \%$.

\section{Changes in Sediment Yield}

To analyze the effect of land-use changes on watershed conservation, we estimated erosion and sediment yield using the Gavrilovic's model (Emmanouloudis et al. 2003, De Vente and Poesen 2005). Parameters of the model and their spatial 
distribution are presented in Appendix 2. This method estimates sediment yield $(\mathrm{G})$ as the product of an erosion (W) and a sediment delivery (R) component (Eqn 1)

$$
G=\sum \text { Wi.R }
$$

in order to quantify sediment delivery on per watershed basis. For this analysis, the study area included 10 watersheds. Erosion is calculated in a GIS environment, on a per pixel basis (Fig.3, Appendix 2) based on Eqn 2.

$$
W_{i}=T \cdot H \cdot \pi \cdot Z^{\stackrel{3}{2}} \cdot H^{\prime}
$$

where Wi is Gross erosion ( $\mathrm{m}^{3} /$ year), $\mathrm{T}$ is a temperature coefficient, $\mathrm{H}$ is average precipitation (mm/year), $\mathrm{Z}$ is an erosion coefficient, and $\mathrm{F}$ is the area of the pixel $\left(0.007396 \mathrm{~km}^{2}\right)$.

The temperature coefficient $\mathrm{T}$ is defined by Eqn 3,

$$
T=\left(\frac{t_{m}}{10}+0.1\right)^{\frac{1}{2}}
$$

where $\mathrm{t}_{\mathrm{m}}=$ average annual temperature $\left({ }^{\circ} \mathrm{C}\right)$. In our case, to calculate the temperature coefficient we used a $1 \mathrm{~km}$ resolution raster with the average temperature for 1960-2000 (NETBIO1) from the Worldclim database (http://www.worldclim.org).

$\mathrm{H}$ was based on a rainfall map, that we produced using a dot-shaped file with the average values for the years 1966-1976 of available rain station data $(n=21)$ and our own estimates for the mountain region based on vegetation $(n=23)$, which closely reflect the topography-controlled changes in rainfall (Bianchi and Yanez 1992). With these 44 points, we interpolated rainfall to the entire study area using a spline-tension method to obtain a raster map with a pixel size of $86 \times 86 \mathrm{~m}$.

Erosion coefficient $\mathrm{Z}$ is defined by Eqn 4

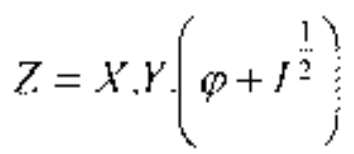

where $\mathrm{X}$ is coefficient of soil cover; $\mathrm{Y}$ is a coefficient of soil resistance; $\phi=$ coefficient of extent of erosion, and I is the slope (Appendix 2). In our case, $\mathrm{X}$ was based on our land-cover analysis using three main categories: forest, urban, and pasture/agriculture. Forest was subdivided in three sub-categories mainly because of climate differences that make forest more dense, intermediate or drier with consequences for soil erosion. Categories for $\mathrm{Y}$ were based on soil characteristics from an available soil map from the National Institute for Agriculture Technology (INTA) and ranked in comparison with each other. $\phi$ was based on satellite images observations and geology of the study area (Mon and Suayter 1973) to estimate coefficients following values used in other studies (Beyer-Portner 1998, De Vente and Poesen 2005). I was calculated using a DEM from the U.S. Geological Survey (http://edc.usgs.gov/pro ducts/elevation.html).

The sediment delivery ratio $(\mathrm{R})$ is calculated using the morphology data for each basin (Eqn 5).

$$
R=\frac{\left[(O . D)^{\prime}(L+L i)\right]}{[(L+10) F]}
$$

where $\mathrm{O}$ is the perimeter of the basin $(\mathrm{km})$; $\mathrm{D}$ is the average elevation of the watershed $(\mathrm{km}) ; \mathrm{Li}$ is the total length of the secondary waterways $(\mathrm{km})$; $\mathrm{L}$ is the length of the principal waterway $(\mathrm{km})$; and $\mathrm{F}$ is the area of the watershed $\left(\mathrm{km}^{2}\right)$. 
Fig. 3. Modeled gross erosion in 1972 (A), 2006 (B), and change between the two dates (C). All figures are in $\mathrm{m}^{3} \mathrm{ha}^{-1}$ year $^{-1}$.

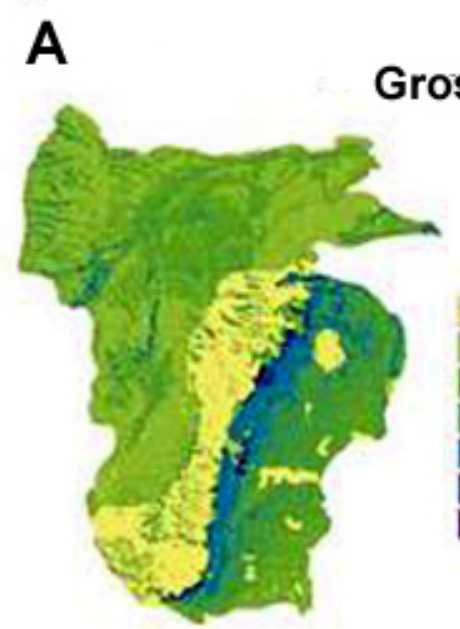

1972

C

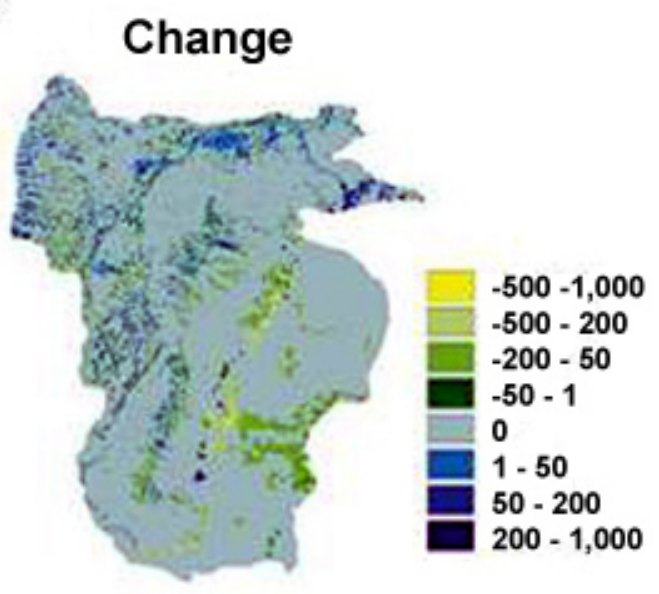

B

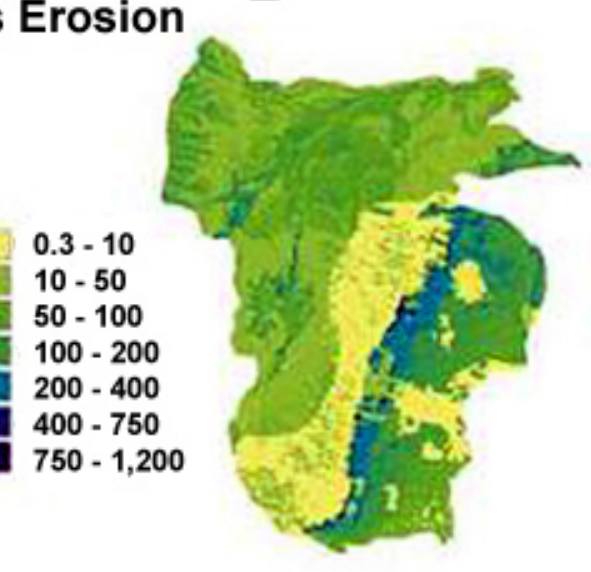

2006
To assess the quality of our estimates, we compared our results with an empirical measurement of suspended sediment load from a small catchment in the Rio Muerto basin (Martenssen 1997). This basin has two rainfall stations, located in the two extremes of the elevational range. This study, conducted during the 1996-1997 rainy season estimated an annual sediment yield of $15.65 \mathrm{Tn} / \mathrm{ha} /$ year. Using an average apparent specific weight of $1,5 \mathrm{Tn} / \mathrm{m}^{3}$ for the loessic sediments from the area, our estimate for the Rio Muerto basin in 2006 corresponds to $17.45 \mathrm{Tn} / \mathrm{ha} /$ year, $11.5 \%$ higher than the empirical observation.

\section{RESULTS}

Forest cover in the study area between 1949 and 2006 showed a clear pattern of forest transition (Figs. 2, 4). In the complete study area between 1972 and 2006, forest area increased by ca. 1371 ha, 
Fig. 4. Changes in the area of forest; the solid line represents the complete study area, the dotted line represents the area included in the 1949 aerial photographs.

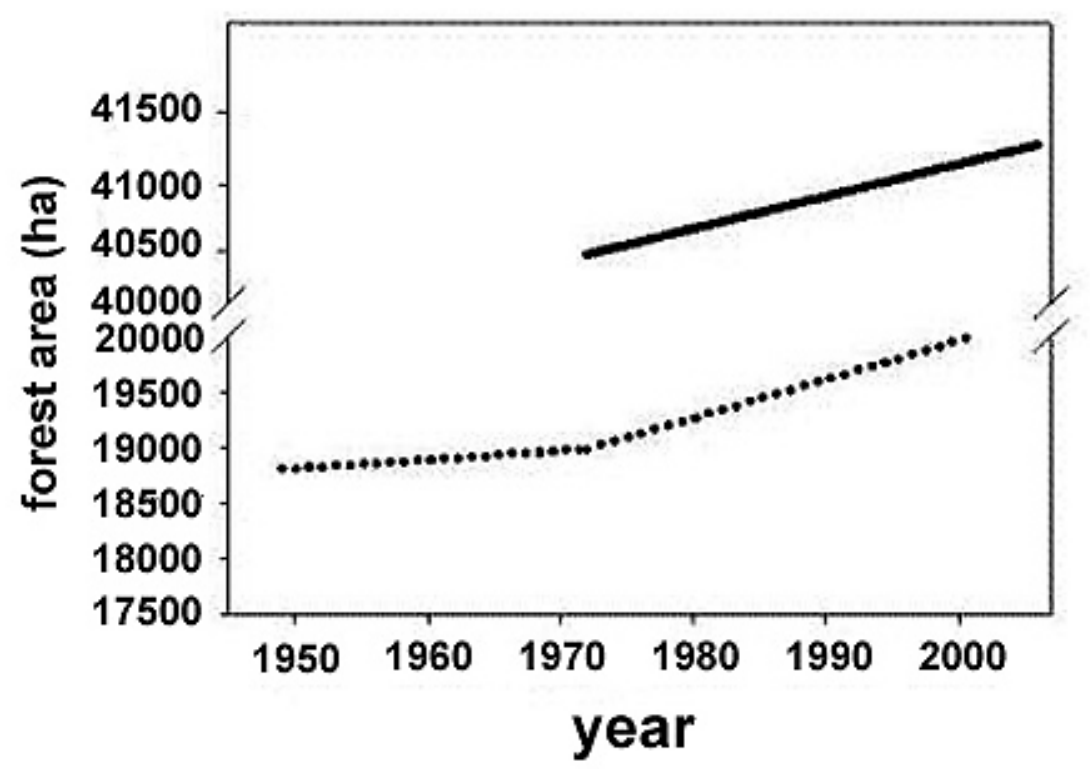

which is the net balance of 5512 ha of agricultural fields converted into forests and 4111 ha of forests transformed into agricultural fields (Table 1). Despite the occurrence of these new agricultural areas, net agricultural area decreased by 3377 ha; $73 \%$ of the disappearing agricultural land was transformed into new forests and $27 \%$ into urban areas, which in turn showed a net increase of 1978 ha (Table 1). Between 1972 and 2006, the general trend of forest expansion was the same within the area included in the 1949 aerial photographs (Fig. 4 ), which showed a slight increase in forest cover between 1949 and 1972 (ca. 100 ha), thus suggesting that forest expansion may have started earlier but was accelerated during the last decades. Forest expansion occurred both inside and outside the protected area. Of the 5512 new forests regenerated between 1972 and 2006, 1372 occurred within the protected area, and 4140 ( $75 \%$ of the total) occurred outside. Specific areas of forest expansion include the southern sector of the sierra ridge and the eastern foothills, whereas deforestation mainly occurred in the north of the study area (Fig. 2). In the southern sector of the sierra, the area of Ligustrum forests was 539 ha (Fig.5) by 2001.
Modeled soil erosion changed as a consequence of land-use changes (Fig. 3). The western and northern valleys showed a combination of both increases of sediment yield due to deforestation, and decreases due to forest recovery. In contrast, sediment yield clearly decreased along the upper ridge of the sierra and particularly in the eastern foothills due to increases in forest cover, and in the eastern side of the study area due to urbanization. Modeled total sediment yield decreased by ca. $10 \%$, and this decrease occurred in eight out of 10 watersheds analyzed (Fig. 6).

\section{DISCUSSION}

Our study documented a case of peri-urban forest transition in the subtropical region of Argentina, with clear implications for the conservation of environmental services, and with a salient feature: a significant proportion of the new forests are dominated by an exotic tree species.

In the Sierra de San Javier, forest expansion probably started during the second half of the $20^{\text {th }}$ century, and accelerated over the last 30 years (Figs. 
Table 1. Transition matrix (in hectares) of main land-cover types between 1972 and 2006 in the study area

\begin{tabular}{cccc}
\hline \hline & & 2006 & \\
\hline 1972 & Agriculture-pasture & forest & urban \\
Agriculture-pasture & 21087 & 5512 & 1978 \\
forest & 4111 & 35896 & 1 \\
urban & 1 & 0 & 1270 \\
\hline
\end{tabular}

$2,4)$. In addition to the quantitative information provided by the remote-sensing analysis, this process was documented by comparative historical photographs (Grau 1985), which indicate that the pattern reported here is highly reliable. Although forest recovery has been reported in other peri-urban Neotropical areas (López et al. 2001, Baptista 2008, Parés-Ramos et al. 2008), it contrasts with the general urban public perception of the effect of urban expansion on the surrounding environments in Argentina, and other Neotropical regions (Grau et al. 2007). Moreover, our study indicates that the process is leading to an improvement of the most perceived environmental service on a mountain area neighboring an expanding urban center: watershed conservation. Watershed condition has clearly improved during the last 30 years in the study area (Figs. 3, 6). Our study showed that during years of similar rainfall, present-day conditions of the sierra yield ca. $10 \%$ less sediment than in the early 1970s, implying better soil conservation largely due to the expansion of forest cover in the zones near urban centers. The effect of forest recovery on the reduction of sediment yield is disproportionately high due to the recovery of forest on areas especially sensitive to erosion due to steep slopes and high rainfall. Forest recovery on areas of steep slopes in montane forest zones have been observed in other regions, such as Costa Rica (Helmer 2000), Puerto Rico (Lopez et al. 2001, Parés-Ramos et al. 2008), and the Dominican Republic (Grau et al. 2008), and seems to be a frequent pattern favoring watershed conservation. It must be acknowledged, however, that our study does not take into account differences in forest type. The properties of exotic-dominated forests in terms of hydrology should be further studied. For example, the high vegetation signature of Ligustrum forests in satellite images taken during the dry season (e.g., low reflectance in the red and high reflectance in the near-infrared bands) and the high growth rates of this species compared with native ones (Easdale et al. 2007), suggest a greater water consumption with potential consequences for watershed dynamics. Forest biomass accumulation due to decreasing logging activities in the area (not quantified in this study) is also probably leading to better watershed conditions. Also, we did not consider differences caused by changes in crops (e. g., sugar cane and citrus), which do influence sediment yield (Hunzinger 1997)

The importance of exotic species on new forests also implies that the effects of the forest transition on biodiversity, although generally positive, are not straightforward. Secondary forests promote the fast recovery of local species richness of trees (Grau et al. 1997). However, Ligustrum-dominated forests, which represent a growing proportion of secondary forests (Aragón and Morales 2003, Fig. 5) have reduced species richness of trees and lianas when compared with native forests of similar age (Lichstein et al. 2004). In addition, other exotic species dominate some new secondary forests, including Morus alba of Asian origin and Gleditizia triacanthos of North American origin (Grau and Aragón 2000), and their ecological consequences also need to be studied. This study did not assess effects of the forest transition on animal wildlife but some speculations can be derived. Expanding forest certainly provides increasing habitat for native biodiversity, and in a few decades, local richness of mammals (Bustos 1995) and birds (Rougès and Blake 2001) increases significantly. However, exotic trees tend to produce fruits during the dry 
Fig. 5. Distribution of Ligustrum lucidus monodominant stands in 2001 (in green) in the southern sector of the study area.

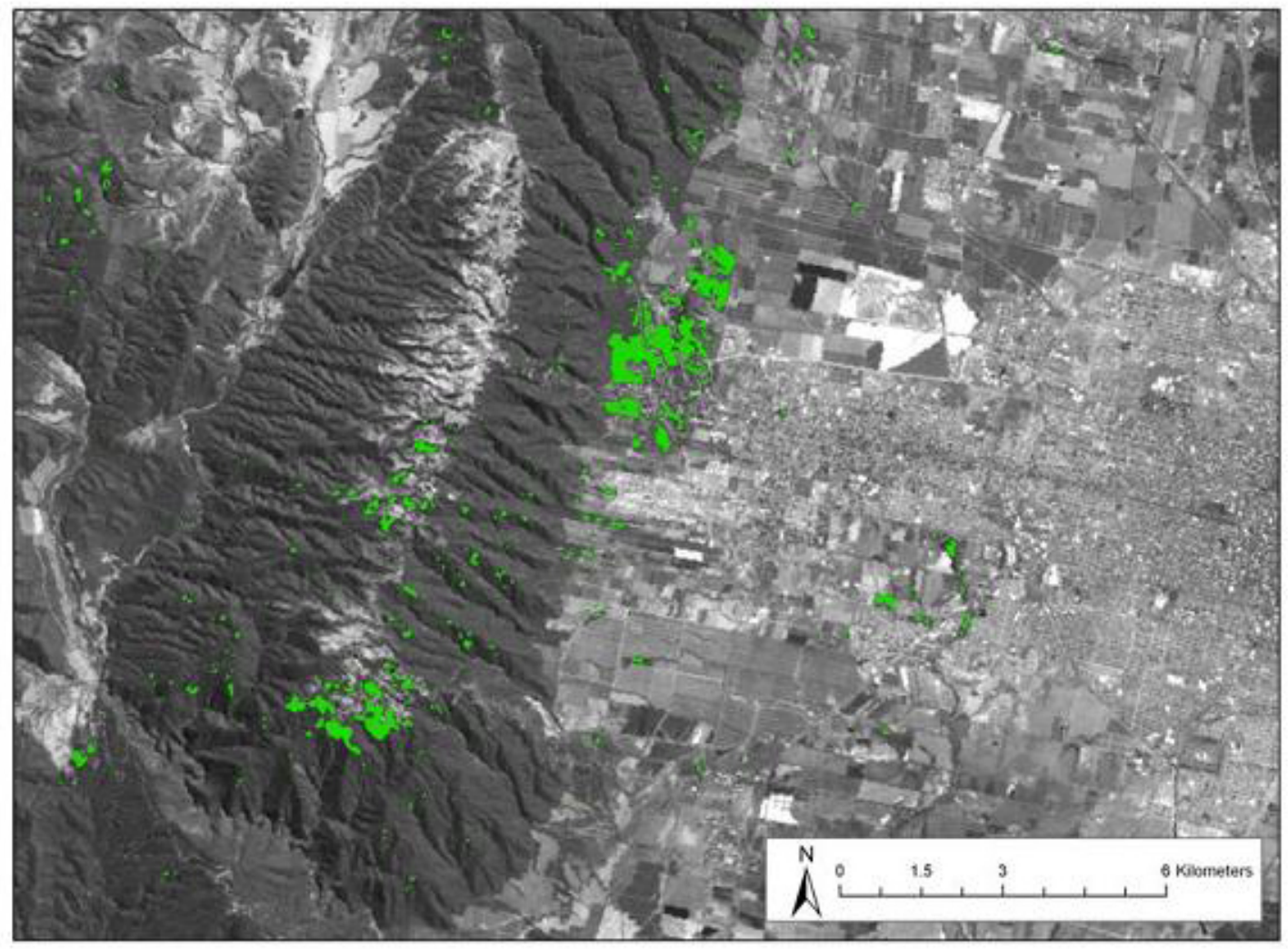

winter whereas most native fleshy fruit species produce fruits during the rainy summer (Grau and Aragón 2000); this different phenological pattern appears to influence the behavior of frugivore communities (Aragón 2000, Rougès and Blake 2001). Socioeconomic changes leading to a more urban life style, coupled with formal protection of some areas, are likely reducing hunting pressures (Maria Eugenia Hernández and Pablo Jayat, National University of Tucumán, personal communication), potentially leading to a population recovery for large mammals, strongly reduced in the past due to hunting and collection of live birds.

Can these benefits derived from forest transition be expected in other peri-urban ecosystems? The topographic characteristics of the area certainly favored forest recovery in our study area. Forests tended to regenerate in areas of steep slopes, which are not suitable for modern agriculture and cannot compete with extensive flat areas with fertile soils characteristic of the region, thus promoting land abandonment (Izquierdo and Grau 2008). Consequently, these land-cover patterns could be expected in montane peri-urban areas with steep slopes. Legal protection due to the creation of the protected area of the University of Tucumán may have favored forest recovery, but the fact that forests expanded both inside and outside the protected area suggests that the process is largely due to other socioeconomic changes. Most of the forest expansion occurred in locations close to the urban 
Fig. 6. Relative change (\%) in modeled sediment between 1972 and 2006 in the different watersheds of the study area. $\mathrm{T}$ indicates the total study area.
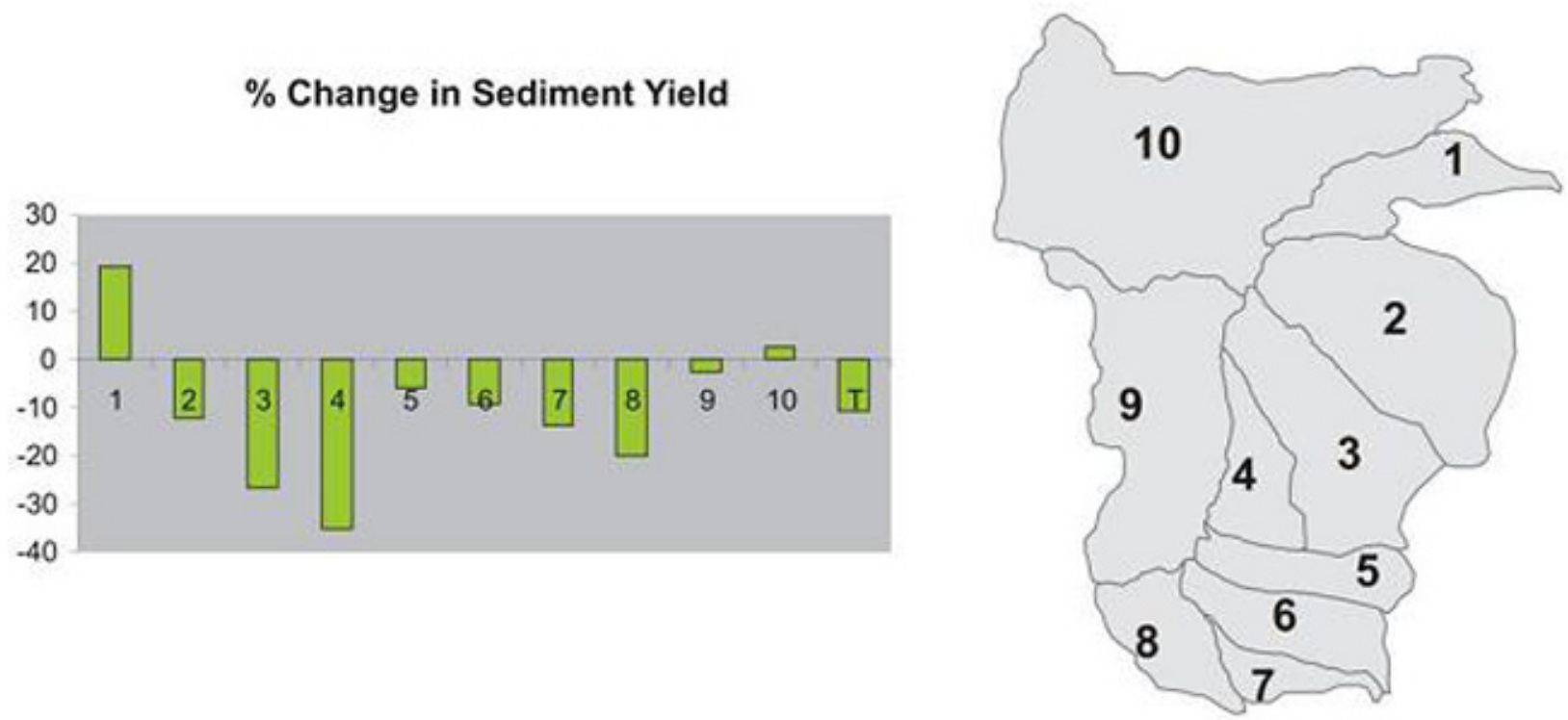

expansion (Fig. 2), suggesting that socioeconomic changes associated with population urbanization, such as the availability of non-farming jobs, play a key role in favoring the abandonment of marginal agriculture lands and thus, forest recovery. In summary, this study suggests that peri-urban areas with low value for modern agriculture, which are experiencing socioeconomic changes leading to service- and industry-based economies, may benefit from processes of forest transition, which in turn may have positive consequences for the conservation of environmental services for large and growing urban populations.

\section{CONCLUSIONS}

The analysis of LUC changes in the Sierra de San Javier provides a well-documented case of forest transition in an area neighboring San Miguel de Tucumán, an intermediate-sized city (ca. 1 million people). During the last three decades, forests have expanded mostly over areas where marginal agriculture has decreased in intensity. The expansion of forests likely promotes watershed and biodiversity conservation. However, as observed in other peri-urban forest transitions (Grau et al. 2003, Lugo and Helmer 2004), new forests are largely affected by exotic invasive species that, in some cases, slow biodiversity recovery and in general make new forests ecologically different from the original ones, thus deserving specific assessments of the ecological effects of exotic species invasion. The patterns described here could be representative of peri-urban Neotropical areas where steep slopes limit the potential for modern agriculture, and thus provide an opportunity for the conservation of environmental services affecting large and aggregated human populations.

Responses to this article can be read online at: http://www.ecologyandsociety.org/voll3/iss 1/art35/responses/ 


\section{Acknowledgments:}

This study was made possible thanks to funds provided by PICT-O 2004 \#816 from the Argentine Fund for Science and Technology (FONCYT), a CIUNT grant from the National University of Tucumán, and a Russell Train grant to Cristina Casavecchia. NSF grant \#DEB-0731594 provided funds for this publication and travel costs to attend the meeting of the Association for Tropical Biology and Conservation (Morelia 2007) where this special feature originated. Mitch Aide, Sandra Baptista, Tania Lopez, Pablo Jayat, and one anonymous reviewer provided useful comments on early manuscripts

\section{LITERATURE CITED}

Aide, T. M., and H. R. Grau. 2004. Globalization, migration, and Latin American ecosystems. Science 305:1915-1916.

Aide, T. M., J. K. Zimmerman, J. B. Pascarella, L. Rivera, and H. Marcano-Vega. 2000. Forest regeneration in a chronosequence of tropical abandoned pastures: implications for restoration ecology. Restoration Ecology 8:328-338.

Aragón, R. 2000. Especies exóticas como recursos para las aves en bosques secundarios de las Yungas. Pages 21-35 in H. R. Grau, and R Aragón, editors. Ecología de árboles exóticos de las Yungas argentinas. LIEY - UNT, Tucumán, Argentina

Aragón, R., and J. M. Morales. 2003. Species composition and invasion in NW Argentina secondary forests: effects of land use history, environment and landscape. Journal of Vegetation Science 14:195-204.

Arturi , M. F., H. R. Grau, P. G. Aceñolaza, and A. D. Brown. 1998. Estructura y sucesión en bosques montanos del Noroeste de Argentina. Revista de Biología Tropical 46:525-532.

Baptista, S. R. 2008. Human dimensions of forest recovery in the metropolitan region of Florianópolis, Santa Catarina state, southern Brazil. Ecology and Society: in press.
Beyer-Portner, N. 1998. Érosion des bassins versant alpins suisses par ruissellement de surface. Dissertation. Laboratoire de Constructions HydrauliquesLCH, No. 1815, Laussanne, Switzerland.

Bianchi A. R., and C. Yanez. 1992. Las precipitaciones del noroeste argentino. Instituto Nacional de Tecnología Agropecuaria, Salta, Argentina.

Bustos, M. 1995. Cambios en la comunidad de roedores en la sucesión secundaria de la Sierra de San Javier, Tucumán, Argentina. Pages 115-122 in A. D. Brown, and H. R. Grau, editors. Investigación, conservación y desarrollo en selvas subtropicales de montaña. LIEY - Universidad Nacional de Tucumán, Tucumán, Argentina.

Carilla, J., H. R. Grau, and A. Malizia. 2006. Patterns of forest recovery in grazing fields in the subtropical mountains of northwest Argentina. Pages 263-273 in E. Spehn, M. Lieberman, and C. Körner, editors. Land use change and mountain biodiversity. CRS, Taylor and Francis, Boca Raton, Florida, USA.

De Vente, J., and J. Poesen. 2005. Predicting soil erosion and sediment yield at the basin scale: scale issues and semi-quantitative models. Earth Science Reviews 71: 95-125.

Easdale, T. A., J. R. Healey, H. R. Grau, and A. Malizia. 2007. Tree life histories in a montane subtropical forest: species differ independently by shade-tolerance, turnover rate, and substrate preference. Journal of Ecology 95:1234-1249.

Emmanouloudis, D. A., O. P. Christou, and E. Filippidis. 2003. Quantitative estimation of degradation in the Aliakmon river basin using GIS. Pages 234-240 in D. De Boer, W, Froehlich, T. Mizuyama, and A. Pietroniro, editors. Erosion prediction in ungauged basins: integrating methods and techniques. IAHS Publication 279.

Foody, G. M. 2002. Status of land cover classification accuracy assessment. Remote Sensing of the Environment 80:185-201.

Foster, D. 1992. Land use history (1730-1990) and vegetation dynamics in central New England. Journal of Ecology 80:753-771.

Grau, A. 1985. La expansión del aliso del cerro 
(Alnus acuminata subsp. acuminata) en el Noroeste de Argentina. Lilloa 36:237-247.

Grau, H. R., and T. M. Aide. 2008. Globalization and land use transitions in Latin America. Ecology and Society in press.

Grau, H. R., T. M. Aide, J. K. Zimmerman, J. R. Thomlinson, E. Helmer, and X. Zou. 2003. The ecological consequences of socioeconomic and land-use changes in postagricultural Puerto Rico. Bioscience 53:1159-1168.

Grau, H. R., T. M. Aide, J. K. Zimmerman, and J. R. Thomlinson. 2004. Trends and scenarios of the carbon budget in post-agricultural Puerto Rico (1936-2060). Global Change Biology 10:11631179.

Grau, H. R., and R. Aragón R. 2000. Árboles invasores de la Sierra de San Javier, Tucumán, Argentina. Pages 5-20 in H. R. Grau, and R. Aragón, editors. Ecología de árboles exóticos de las Yungas argentinas. LIEY - UNT, Tucumán, Argentina.

Grau, H. R., M. F. Arturi, A. D. Brown, and P. G. Aceñolaza. 1997. Floristic and structural patterns along a chronosequence of secondary forest succession in Argentinean subtropical montane forests. Forest Ecology and Management 95:161171.

Grau, H. R., N. I. Gasparri, M. M. Morales, A. Grau, E.Araoz, J. Carilla, and J. Gutierrez. 2007. Regeneración ambiental en el Noroeste Argentino. Ciencia Hoy 17:42-55.

Grau H. R. M. Perez-Ceballos, S. Martinuzzi, X. Encarnación and T. M. Aide. 2008. Cambios socioeconómicos y regeneración del bosque en la República Dominicana. Pages 221-227 in M. Gonzáles Espinosa, J. M. Rey Benayas and N. Ramírez-Marcial, editors. Restauración de bosques en América Latina. Mundi-Prensa, México.

Hecht,S. B., S. Kandel, I. Gomes, N. Cuellar, and H Rosa. 2006. Globalization, forest resurgence, and environmental politics in El Salvador. World Development 34:308-323.

Helmer, E. 2000. The landscape ecology of tropical secondary forests in montane Costa Rica. Ecosystems 3:98-114.

Hunzinger, H. 1997. Hydrology of montane forests in the Sierra de San Javier, Tucumán, Argentina. Mountain Research and Development 17:299-308.

Izquierdo, A., and H. R Grau. 2008. Agriculture adjustment, land use transition, and protected areas in Northwestern Argentina. Journal of Environmental Management: in press.

Labraga, J.C. 1997. The climate change in South America due to doubling in the $\mathrm{CO}_{2}$ concentration: intercomparison of general circulation model equilibrium experiments. International Journal of Climatology 17:377-398.

Lichstein, J. W., H. R. Grau, and R.Aragón. 2004. Recruitment limitation in secondary forests dominated by an exotic tree. Journal of Vegetation Science 15:721-728.

Lopez, T. M., T. M. Aide, and J. R. Thomlinson. 2001. Urban expansion and the loss of prime agricultural lands in Puerto Rico. Ambio 30:49-54.

Lugo, A. E. 2002. Can we manage tropical landscapes? An answer from the Caribbean perspective. Landscape Ecology 17:601-615.

Lugo, A. E., and H. Helmer. 2004. Emerging forests on abandoned land: Puerto Rico's new forests. Forest Ecology and Management 190:145161.

Martenssen, J. 1997. Metodologías paramétricas y su relación con mediciones en parcelas aplicables a la estimación de erosión en cuencas hidrográficas. Pages 1-5 in Proceedings of the VII Congreso Geológico Chileno. Antofagasta, Chile.

Mather, A. S. 1992. The forest transition. Area 24:367-379.

Mather, A. S. 2001. The transition from deforestation to reforestation in Europe. 2001. Pages 35-52 in A. Angelsen and D. Kaimowitz, editors. Agricultural technologies and tropical deforestation CABI Publishing, Wallingford, UK. 
Mather, A. S., and J. Fairbairn. 2000. From floods to reforestation: the forest transition in Switzerland. Environment and History 6:399-421

Minetti, J. L., and W. M. Vargas. 1997. Trends and jumps in the annual rainfall in South America, south of the $15^{\circ} \mathrm{S}$. Atmosfera 11:205-223.

Mon, R., and L. Suayter. 1973. Geología de la sierra de San Javier (provincia de Tucumán, Argentina). Acta Geológica Lilloana 12:155-168.

Moyano, M. Y., and C. P. Movia. 1989. Relevamiento florístico-estructural de las sierras de San Javier y el Periquillo (Tucumán, Argentina). Lilloa 37:123-135.

Parés-Ramos, I., W. Gould, and T. M. Aide. 2008. Suburban growth and forest expansion following agricultural abandonment in Puerto Rico (19912000). Ecology and Society: in press.

Richards, J. A., and J. Xiuping. 2006. Digital image analysis. An introduction. Springer Verlag, New York, New York, USA.

Rougès, M., and J. Blake. 2001. Tasas de captura y dietas de aves del sotobosque en el Parque Biológico Sierra de San Javier, Tucumán. El Hornero 16:7-15.

Rudel, T. K., O. T. Coomes, E. Moran, F. Achard, A. Angelsen, J. Xu, and E. Lambin. 2005. Forest transitions: towards a global understanding of the land use change. Global Environmental Change 15:2331.

Rudel, T. K., M. Perez-Lugo, and H.Zichal. 2000. When fields revert to forest: development and spontaneous reforestation in post-war Puerto Rico. Professional Geographer 52:386-397.

United Nations Population Fund (UNFPA). 2007. State of the world population. Unleashing the potential of urban growth. [online] URL: http://ww w.unfpa.org/swp/swpmain.htm.

Veblen, T. T., and D. C. Lorenz. 1991. The Colorado front range. A century of ecological change. University of Utah Press, Salt Lake City, Utah, USA.
Wright, S. J. 2005. Tropical forests in a changing environment. Trends in Ecology and Evolution 20:553-560.

Wright, S. J., and H. Muller-Landau. 2006. The future of tropical forest species. Biotropica 38:287301. 
APPENDIX 1. Confusion matrices of land-cover categories in 1972 and 2006 maps.

a) 1972. Total error (Kappa coefficient $\mathrm{x} 100)=88.04$

\begin{tabular}{|c|c|c|c|c|c|c|}
\hline & & \multicolumn{4}{|c|}{ Validation (1968 aerial photograph 1:50 000) } & \multirow[t]{2}{*}{ User precision } \\
\hline & & Agriculture & Forest & Urban & Total & \\
\hline \multirow[t]{5}{*}{ Map } & Agriculture & 168 & 14 & 7 & 207 & 89.86 \\
\hline & Forest & 31 & 189 & 0 & 220 & 85.91 \\
\hline & Urban & 1 & 0 & 15 & 16 & 93.75 \\
\hline & Total & 218 & 203 & 22 & 22 & \\
\hline & Producer pre & 85.32 & 93.10 & 68.18 & 68.18 & \\
\hline
\end{tabular}

b) 2006 . Total error (Kappa coefficient $\mathrm{x} 1000)=87.87$

Validation (2002 and 2006 Google Earth)

\begin{tabular}{|c|c|c|c|c|c|c|}
\hline \multirow[t]{5}{*}{ Map } & Agriculture & 253 & 21 & 20 & 294 & 86.05 \\
\hline & Forest & 52 & 426 & 0 & 478 & 89.12 \\
\hline & Urban & 2 & 3 & 31 & 36 & 86.11 \\
\hline & Total & 307 & 450 & 51 & 808 & \\
\hline & Producer pre & 82.41 & 94.67 & 60.78 & & \\
\hline
\end{tabular}


Appendix 2. Values and spatial distribution of coefficients used in the sediment yield analysis.

$$
\text { Please click here to download file 'appendix2.pdf'. }
$$

